\title{
Faktor-Faktor yang Mempengaruhi Ketepatan Waktu Penyampain Laporan Keuangan pada Perbankan yang Terdaftar di Bursa Efek Indonesia
}

\author{
Abdul Gafar ${ }^{1}$, Lewi Malisan ${ }^{2}$, Irwansyah ${ }^{3}$ \\ Fakultas Ekonomi dan Bisnis Universitas Mulawarman, Indonesia
}

\begin{abstract}
Abstrak
Penelitian bertujuan untuk menganalisis faktor-faktor yang mempengaruhi ketepatan waktu penyampaian laporan keuangan pada perbankan yang terdaftar di bursa efek Indonesia. Faktor-faktor yang diuji dalam penelitian ini adalah Profitabilitas, Likuiditas, Solvabilitas dan ukuran Perusahaan sedangkan ketepatan waktu sebagai variabel dependen. Sampel penelitian ini terdiri dari 15 perusahaan yang terdaftar di bursa efek Indonesia (BEI) yang menyampaiakan laporan keuangan ke Bapepam dalam periode 2010-2014. Data yang digunakan dalam penelitian adalah data skunder dan pemilihan sampel yang menggunakan metode purposive. Alat analisis yang digunakan adalah Analisis Regresi Logistik pada tingkat signifikan 5\%. Hasil pengujian hipotesis menunjukkan bahwa profitabilitas, likuiditadap berpengaruh signifikan terhadap ketepatan waktu penyampaian laporan keuangan. Akan tetapi, tidak ditemuakan bukti bahwa solvabilitas dan ukuran perusahaan berpengaruh signifikan terhadap ketepatan waktu enyampaian laporan keuangan.
\end{abstract}

Kata Kunci: Ketepatan Waktu, Profitabilitas, Likuiditas Solvabilitas dan Ukuran Perusahaan.

\section{Factors Affecting the Timeliness of Financial Statement Disbursement on Banks Listed on Indonesia Stock Exchange}

\begin{abstract}
The study aims to analyze the factors affecting the timeliness of financial reports on banks listed on the stock exchanges of Indonesia. Factors tested in this study are Profitability, Liquidity, Solvency and size of the company, while timeliness as the dependent variable. The research sample consisted of 15 companies listed on the Indonesia Stock Exchange (IDX), which deliver the financial report to Bapepam in 2010-2014. The data used in this research is secondary data and sample selection using purposive. The analysis tool used is the Logistic Regression Analysis at the 5\% significance level. Hypothesis testing results indicate that profitability, liquidity significantly influence the timeliness of financial reports. However, no evidence that the size of the company's solvency and significantly influence the timeliness of financial reports.
\end{abstract}

Keywords: Timeliness, Profitability, Liquidity and Solvency Company Size. 


\section{PENDAHULUAN}

Media komunikasi yang umumnya digunakan untuk menghubungkan perusahaan dengan pihak eksternal adalah laporan keuangan. Di dalam laporan keuangan tercantum sebagian informasi keuangan yang bermanfaat sebagai bahan pertimbangan dalam pengambilan keputusan ekonomi. Laporan keuangan dirancang sedemikian rupa supaya dapat digunakan oleh semua pihak yang berkepentingan terhadap perusahaan. Pihak eksternal perusahaan yang umumnya menggunakan laporan keuangan adalah pemegang saham, calon investor, kreditor, bank, kantor pelayanan pajak (KPP), dan lain-lainn. Pada umumnya mereka tidak dapat secara bebas memperoleh informasi yang diinginkan karena informasi yang mereka peroleh terbatas pada laporan keuangn yang disediakan oleh menajemen perusahaan.

Kebutuhan akan ketepata waktu pelaporan keuangan secara jelas telah disebutkan dalam kerangka dasar penyusunan penyajian laporan keuangan bahwa ketepatan waktu merupakan salah satu karakteristik yang harus dipenuhi agar laporan keuangan yang disajikan relevan untuk pembuat keputusan. Semakin cepat informasi diungkapkan, maka akan semakin relevan informasi tersebut bagi para pengguna laporan keuangan. Pengguna laporan keuangan sangat membutuhkan informasi yang tepat waktu untuk memungkinkan mereka dapat dengan segera melakukan analisis dan membuat keputusan tentang modal yang sudah, atau akan diinvestasikan pada perusahaan. Profesi akuntansi pun mengakui akan kebutuhan terhadap ketepatan waktu penyampaian laporan keuangan. Tanggungjawab ini ditunjukkan dalam pekerjaan akuntan yang selalu berusaha bekerja lebih profesional agar tepat waktu dalam menyajikan laporan keuangan.

Setiap perusahaan yang go public memiliki kewajiban untuk menyampaikan laporan keuangan yang disusun sesuai dengan standar akuntansi keuangan dan telah diaudit tepat waktu. Tuntutan akan kepatuhan terhadap ketepatan waktu dalam penyampaian laporan keuangan publik di Indonesia telah diatur dalam UU No. 8 tahun 1995 tentang Pasar Modal dan selanjutnya diatur dalam Keputusan Ketua BAPEPAM No. 80/PM/1996. Dalam peraturan ini disebutkan bahwa emiten dan perusahaan publik wajib menyampaikan laporan keuangan tahunan yang telah diaudit oleh akuntan independen, selambatlambatnya pada akhir bulan keempat (120 hari) setelah tanggal laporan keuangan perusahaan. Namun kemudian Bapepam memperketat peraturan dengan dikeluarkannya Keputusan Ketua BAPEPAM Nomor 36/PM/2003 tentang Kewajiban Penyampaian Laporan Keuangan Berkala. Dalam lampirannya, yaitu Peraturan BAPEPAM Nomor X.K.2, disebutkan bahwa laporan keuangan tahunan harus disertai dengan laporan akuntan dengan pendapat yang lazim dan disampaikan kepada Bapepam selambat-lambatnya pada akhir bulan ketiga (90 hari) setelah tanggal laporan keuangan.

Sehubungan dengan adanya program konvergensi pernyataan Standar Akuntansi Keuangan (PSAK) ke International Financial Reporting Standar (IFRS), keputusan Ketuan BAPEPAM Nomor KEP-36/PM/2003 dinyatakantidakj berlaku mulai juli 2011. Kewajiban penyampaian laporan keuangan tahunan oleh perusahaan go public saat ini diatur dalam Keputusan Ketua BAPEPAM dan lembaga keuangan nomor: KEP-346/BL/2011 tanggal 5 juli 2011. Dalam peraturan tersebut perusahaan go public diwajibkan untuk menyampaikan laporan keuangan tahunan yang disertai dengan laporan auditor independen kepada Badan Pengawas Pasar Modal Dan Lembaga Keuangan selambat-lambatnya 90 hari setelah tanggal laporan keuangan tahunan.

Dengan disahkan Undang-Undang Republik Indonesia Nomor 21 tahun 2011 tentang Otoritas Jasa Keuangan, mulai awal tahun 2013 Badan Pengawas Pasar Modal dan Lembaga Keuanganyang selam ini berada dibaah kementerian keuangan, fungsinya telah digantikann oleh otoritas jasa keuangan. Sehingga otomatis saat ini perusahaan go public wajib menyampaikan laporan keuangan tahunan yang disertai dengan laporan auditor independen kepada Otoritas Jasa Keuangan.

Perusahaan yang terlambat dalam menyampaikan laporan keuangan secara tepat waktu akan dikenakan sanksi administrasi dan denda, sesuai dengan ketentuan yang ditetapkan oleh undang-undang. Meskipun demikian, dari tahun ke tahun tetap saja masih banyak perusahaan publik yang terlambat dalam menyampaikan laporan keuangan tahunannya. Sebagai contoh: hingga pertengahan bulan April 2009, menurut laporan Badan Pengawas Pasar Modal 
dan Lembaga Keuangan (Bapepam LK) mencatat masih banyak perusahaan yang tidak tertib dalam penyampaian laporan keuangan auditan untuk periode yang berakhir 31 Desember 2008. Perusahaan yang terlambat tersebut akan dikenakan denda Rp 1.000.000,per hari (Berita Bisnis dalam inilah.com, 22 April 2009).

Selain sanksi administrasi dan denda oleh Bapepam dan LK, Bursa Efek Indonesia (BEI) juga dapat memberikan sanksi dan denda kepada perusahaan publik yang terlambat menyampaikan laporan keuangan tahunan auditan melebihi batas waktu yang telah ditetapkan oleh bursa. Bursa Efek Indonesia (BEI) melalui keputusan direksi PT. Bursa Efek Jakarta Nomor 306/BEJ/07-2004 menerbitkan peraturan pencatatan berkala Nomor I-E tentang kewajiban penyampaian informasi yang batas waktu penyampaiannya disesuaikan dengan peraturan

Bapepam No. X.K.2. Bursa Efek Indonesia juga menerbitkan keputusan direksi PT. Bursa Efek Jakarta Nomor 307/BEJ/07-2004 yaitu Peraturan Nomor I-H Tentang Sanksi. Bagi perusahaan yang tidak patuh terhadap peraturan tersebut, disebutkan ada empat bentuk sanksi yang dikenakan terdiri atas : 1) Peringatan tertulis I, atas keterlambatan penyampaian laporan keuangan sampai 30 (tiga puluh) hari kalender terhitung sejak lampaunya batas waktu penyampaian laporan keuangan; 2) Peringatan tertulis II dan denda Rp 50.000.000,- apabila mulai hari kalender ke 31 hingga kalender ke 60 sejak lampaunya batas waktu penyampaian laporan keuangan, perusahaan tercatat tetap tidak memenuhi kewajiban menyampaikan laporan keuangan; 3) Peringatan tertulis III dan denda Rp 150.000.000,- apabila mulai hari kalender ke 60 hingga kalender ke 90 sejak lampaunya batas waktu penyampaian laporan keuangan perusahaan tercatat tetap tidak memenuhi kewajiban menyampaikan laporan keuangan atau menyampaikan laporan keuangan namun tidak memenuhi kewajiban untuk membayar denda sebagaimana dimaksud pada ketentuan peraturan II di atas; 4) Penghentian sementara perdagangan dalam hal kewajiban laporan keuangan dan atau denda tersebut di atas belum dilakukan oleh perusahaan.

Keluarnya peraturan-peraturan tersebut merupakan cerminan bahwa pihak pembuat peraturan (regulator) cukup serius menanggapi kasus ketidakpatuhan dalam penyampaian laporan keuangan. Menurut pengumuman Bursa Efek Indonesia (Peng-LK-00266/BEI.PSR/06-2009, Peng-LK-00289/BEI.PSJ/06-2009) terdapat 13 (tiga belas) Perusahaan Tercatat yang hingga tanggal 29 Mei 2009, belum menyampaikan Laporan Keuangan Auditan untuk Periode yang Berakhir per 31 Desember 2008. Sehingga, mengacu pada ketentuan bursa, Bursa Efek Indonesia (BEI) telah memberikan Peringatan Tertulis III dan denda sebesar Rp 150.000.000,- kepada 13 (tiga belas) perusahaan tersebut. Selain tuntutan untuk mematuhi peraturan-peraturan tersebut, ketepatan waktu dalam penyampaian laporan keuangan merupakan hal penting yang harus dipenuhi oleh perusahaan karena: 1) Mematuhi prinsip keterbukaan di pasar modal Indonesia dan menghindari adanya spekulasi dalam perdagangan saham perusahaan; 2) Memenuhi hak investor publik yang menanamkan modal di perusahaan untuk memperoleh informasi laporan keuangan perusahaan dengan segera; 3) Meningkatkan good governance emiten di Indonesia; dan 4) Menjaga image atau citra perusahaan di mata publik. Berdasarkan fakta-fakta tersebut maka perlu diketahui faktor-faktor apa saja yang dapat mempengaruhi ketepatan waktu penyampaian laporan keuangan perusahaan kepada publik.

Penelitian mengenai faktor apa saja yang mempengaruhi ketepatan waktu penyampaian laporan keuangan perusahaan publik ini, telah banyak dilakukan dan berkembang baik di Indonesia maupun di negara-negara lain. Penelitian-penelitian sebelumnya telah menemukan bukti empiris bahwa keterlambatan penyampaian laporan keuangan dipengaruhi oleh beberapa faktor seperti: berita buruk perusahaan, seperti keterlambatan pelaporan dihubungkan dengan kesulitan keuangan (financial distress) perusahaan, kerugian perusahaan, pendapat selain unqualified opinion oleh auditor, dan keterlambatan audit.

Givoli dan Palmon (1982) mengemukakan bahwa adanya berita buruk (bad news) akan menyebabkan perusahaan akan menunda penyampaian laporan keuangannya, sebaliknya adanya berita baik (good news) akan membuat perusahaan lebih tepat waktu dalam menyampaikan laporan keuangannya. Adapun good news misalnya tingginya profitabilitas, likuiditas, yang tinggi dan wajar, 
solvabilitas yang rendah, serta diperolehnya opini wajar tanpa pengecualian yang rendah (WTP) dari kantor akuntan public (KAP).

Beberapa penelitian terdahulu memberikan gambaran mengenai bagaimana profabilitas, likuiditas, solvabilitas, dan opini akuntan puiblik berpengaruh terhadap ketepatan waktu penyampaian laporan keuangan perusahaan. Penelitian respati (2004) menunjukkan hasil bahwa profitabilitas tidak berpengaruh signifikan dan solvibilitas tidak berpengaruh signifikan terhadap ketepatan waktu penyampaian laporan keuangan. Hasil penelitian yang sama juga ditunjukkan oleh penelitian yang dilakukan oleh Hilmi dan Ali (2018). dan Nasir (2012). Hilmi dan Ali (2008) memasukkan variable likuiditas dalam penelitiannya menunjukkan likuiditas berpengaruh signifikan terhadap ketepatan waktu penyampaian laporan keuangan. Selain itu Kasneli (2009) menambahkan variabel opini akuntan public dalam penelitian dan hasilnya menunjukkan opini akuntan public berpengaruh signifikan terhadap ketepatan waktu penyampaian laporan keuangan.

Berawal dari hasil penelitian terdahulu tersebut maka penulis mencoba untuk melakukan penelitian ulang (replikasi). Objek dalam penelitian ini adalah perusahaan perbankan yang terdaftar di Bursa Efek Indonesia periode tahun 2010 hingga 2014. Adapun alasan memilih perusahaan perbankan sebagai objek karena selama empat tahun terkhir perusahaan yang bergerak di sector tersebut rata-rata ketepatan waktunya $81 \%$. Digunakan empat periode dalam penelitian ini dengan alas an untuk dapat melihat konsistensi pengaruh masing-masing variabel independen terhadap variabelo dependen. Dalam penelitian ini hanya menggunakan empat variabel independen yaitu profitabilitas, likuiditas, solvabilitas, dan opini akuntan public. Hal ini dikarenakan hanya 4 variabel tersebut yang berhubungan dengan logika teori yang ada.

Profitabilitas yang tinggi merupakan berita baik (good news) sehingga perusahaan akan cenderung lebih tepat waktu dalam mempublikasikan laporan keuangannya. Sebaliknya, profitabilitas yang rendah merupakan berita buruk (bad news) sehingga perusahaan akan cenderung terlambat dalam mempublikasikan laporan keuangannya. Likuiditas yang tinggi merupakan berita baik (good news) sehingga perusahaan akan cenderung lebih tepat waktu dalam mempublikasikan laporan keuangannya. Sebaliknya, likuiditas yang rendah merupakan berita buruk (bad news) sehingga perusahaan akan cenderung terlambat dalam mempublikasikan laporan keuangannya. Solvabilitas yang rendah merupakan berita baik (good news) sehingga perusahaan akan cenderung lebih tepat waktu dalam mempublikasikan laporan keuangannya. Sebaliknya solvabilitas yang tinggi merupakan berita buruk (bad news) sehingga perusahaan akan cenderung terlambat dalam mempublikasikan laporan keuangannya. Perusahaan yang laporan keuangannya diberi opini wajar tanpa pengecualian merupakan berita baik (good news) sehingga cenderung lebih tepat waktu dalam mempublikasikan laporan keuangannya.

Berdasarkan luraian diatas, penulis melakukan penelitian dengan mengangkat judul "Faktor-Faktor Yang Mempengaruhi Ketepatan Waktu Penyampaian Laporan Keuangan Pada Perbankan Yang Terdaftar Di Bursa Efek Indonesia (BEI)”.

\section{KAJIAN PUSTAKA}

Kepatuhan berasal dari kata patuh, yang menurut Kamus Umum BahasaIndonesia, patuh berarti suka menurut perintah, taat kepada perintah atau aturandan berdisiplin. Kepatuhan berarti bersifat patuh, ketaatan, tunduk, patuh padaajaran atau peraturan.

Tuntutan akan kepatuhan terhadap ketepatan waktu dalam penyampaianlaporan keuangan tahunan perusahaan publik di Indonesia telah diatur dalamUndang-Undang No. 8 Tahun 1995 tentang Pasar Modal, dan selanjutnya diatur dalam Peraturan BAPEPAM Nomor X.K.2, Lampiran Keputusan Ketua BAPEPAM Nomor: KEP-36/PM/2013 tentang Kewajiban Penyampaian Laporan KeuanganBerkala. Peraturan-peraturan tersebut secara hukum mengisyaratkan adanyakepatuhan setiap perilaku individu maupun organisasi (perusahaan publik) yangterlibat di pasar modal Indonesia untuk menyampaikan laporan keuangan tahunanperusahaan secara tepat waktu kepada BAPEPAM. Hal tersebut sesuai dengan teorikepatuhan (compliance theory). 
Teori kepatuhan telah diteliti dalam ilmu-ilmu sosial khususnya di bidangpsikologi dan sosiologi yang lebih menekankan pada pentingnya proses sosialisasidalam mempengaruhi perilaku kepatuhan seorang individu. Menurut Tyler (dalamSaleh dan Susilowati, 2004) terdapat dua perspektif dasar mengenai kepatuhan hukum yaitu instrumental dan normatif. Perspektif instrumental mengasumsikanindividu secara utuh didorong oleh kepentingan pribadi dan tanggapan-tanggapanterhadap perubahan insentif, dan penalti yang berhubungan dengan perilaku.Perspektif normatif berhubungan dengan apa yang orang anggap sebagai moraldan berlawanan dengan kepentingan pribadi mereka.

Seorang individu cenderung mematuhi hukum yang mereka anggap sesuaidan konsisten dengan norma-norma internal mereka. Komitmen normatif melaluimoralitas personal (normative commitment through morality) berarti mematuhihukum karena hukum tersebut dianggap sebagai keharusan, sedangkan komitmennormatif melalui legitimasi (normative commitment through legitimacy) berartimematuhi peraturan karena otoritas penyusun hukum tersebut memiliki hak untukmendikte perilaku (Sudaryanti,2008).

Teori kepatuhan dapat mendorong seseorang untuk lebih mematuhiperaturan yang berlaku, sama halnya dengan perusahaan yang berusaha untukmenyampaikan laporan keuangan secara tepat waktu karena selain merupakansuatu kewajiban perusahaan untuk menyampaikan laporan keuangan tepat waktu,juga akan sangat bermanfaat bagi para pengguna laporan keuangan.

Hubungan agensi dikatakan telah terjadi ketika suatu kontrak antara seseorang atau lebih (seseorang principal) dan orang lain (seorang agen) untuk memberikan jasa demi kepentingan principal termasuk melibatkan adanya pemberian delegasi kekuasaan pengambilan keputusan kepada agen. Baik principal maupun agen diasumsikan untuk termotivasi hanya oleh kepentingan dirinya sendiri. Agen berjuang untuk memaksimalkan pembayaran kontraknya yang bergantung pada suatu tingkatan usaha tertentu yang dibutuhkan. Perinsipal berjuang untuk memaksimalkan pengambilan atas penggunaan sumber dayanya yang terutang ke agen (Jensen dan Meckling, 1976 dalam Belkaoui,2007).

Pemegang saham menunjuk manajeman sebagai orang profesional untuk mengelola perusahaannya. Dengan harapan jika perusahaan. Dengan harapan jika perusahaan dikelola dengan baik akan menghasilkan hasil (return) yang besar bagi bagi pemegang saham dalam bentuk dividen, serta akan meningkatkan nilai saham dan harga pasar saham (Agoes dan Hoesada, 2009:116). Agar pihgak manajemen dapat membuat keputusan atas nama para pemegang saham, merupakan hal yang paling agar pihak manajemen tidak hanya mendapat insentif yang tepat (gaji, bonus, opsi saham, dan kompensasi), tetapi mereka akan diawasi juga. Audit laporan keuangan, dan secara eksplisit membatasi keputusan pihak manajemen (Horne dan Wachhowiczs, 2007:244)

Manejer sebagai agen yang mengelola perusahaan lebih banyak mengetahui informasi internal dan prospek perusahaan dimasa yang akan datang dibandingkan principal.situasi ini akan memicu timbulnya suatu kondisi yang disebut sebagai asimetri infrmasi adalah suatu kondisi dimana principal tidak memiliki informasi yang tidak mencukupi mengenai kinerja agen dan tidak pernah dapat merasa pasti bagaiman usaha agen memberikan kontibusi pada hasil aktial perusahaan. Dalam hal ini ketepatan waktu dalam penyampaian laporan keuangan akan mengurangi asimetri informasi.

\section{METODE PENELITIAN}

Populasi adalah kumpulan individu atau obyek penelitian yang memiliki kualitas-kualitas serta ciri-ciri yang ditetapkan. Berdasarkan kualitas dan ciri tersebut, populasi dapat dipahami sebagai sekelompok individu atau obyek pegamatan yang minimal memiliki satu persamaan karakteristik. Populasi dari penelitian ini adalah seluruh perusahaan di sektor perbankan yang terdaftar di BEI (Bursa Efek Indonesia)

Jenis data yang digunakan dalam penelitian ini adalah data skunder. Data skunder mengacu pada informasi yang dikumpulkan dari sumber yang telah ada (Sekaran, 2006:60). Data skunder yang digunakan dalam penelitian ini meliputi IDX Fact Book, laporan keuangan tahunan yang disertai laporan auditor independen, dan bukti pengumuman penyampaian lapooran keuangan auditan perusahaan sektor 
perbankan yang terdaftar di Bursa Efek Indonesia priode tahun 2010-2013. Seluruh data skunder tersebut bersumber dari situs Web (Website) resmi Bursa Efek Indonesia yaitu http://www.idx.co.id ata yang digunakan dalam peneelitian ini dikumpulkan dengan menggunakan metode penelitian kepustakaan (library research) dan metode dokumentasi. Dalam metode penelitian kepustakaan, penulis membaca dan memahami literatur-literatur berupa artikel media online, buku, jurnal penelitian ilmiah, dan skripsi penelitian terdahulu yang berhubungan dengan penelitian untuk mengetahui teori yang berhubungan dengan masalah yang sedang diteliti. Dalam metode dokumentasi, penulis mengumpulkan data-data berupa IDX Fact Book, laporan keuangan tahunan yang disertai laporan auditor independen, dan bukti pengumuman penyampaian laporan keuangan auditan perusahaan sector perbankan yang terdaftar di Bursa Efek Indonjesia. Dalam penelitian ini menggunakan 4 periode laporan keuangan dengan alasan untuk melihat konsistensi pengaruh masing-masing terhadap variabel dependen. Jumlah sampel perusahaan yang digunakan dalam penelitian ini adalah sebanyak 14 perusahaan pertahun sehingga didapatkan jumlah data $(\mathrm{N})$ sebanyak 56 buah.

Data yang diperoleh diuji dengan menggunakan alat statistik deskriptif. Pengujian statistik dilakukan untuk mengetahui gambaran mengenai variabel-variabel dalam penelitian. Dengan menggunakan software SPSS versi 21 akan dapat diketahui nilai tertinggi, nilai terendah, rata-rata (mean), dan standar deviasi dari masing-masing variabel profitabilitas, dan likuiditas.

Uji multikolinearitas bertujuan untuk menguji apakah dalam model regresi ditemukan adanya korelasi antar variabel independen. Model regresi yang baik seharusnya tidak terjadi korelasi diantara variabel independen.

Uji autokorelasi bertujuan untuk menguji apakah dalam model regresi ada korelasi antara kesalahan penggangu pada periode $\mathrm{t}$ dengan kesalahan penggangu pada periode $\mathrm{t}-1$ (sebelumnya). Autokorelasi muncul karena observasi yang berurutas sepanjang waktu berkaitan sepanjang waktu satu sama lain. Model regresi yang baik adalah regresi yang bebas dari autokorelasi.

Dalam penelitian ini regresi logistik digunakan untuk mengetahui pengaruh variabel-variabel independen terhadap variabel dependen. Adapun model dasar dari regresi logistik menurut Ghozali (2006:228) dapat dirumuskan sebagai berikut:

\section{$\log =\mathbf{a}+\mathbf{b}_{1} \mathbf{x}_{1}+\mathbf{b}_{2} \mathbf{x}_{2}+\mathbf{b}_{3} \mathbf{x}_{3}+\mathbf{b}_{4} \mathbf{x}_{4}+e$}

Keterangan:

\begin{tabular}{|c|c|}
\hline $\log$ & : Probabilitas Timeliness \\
\hline A & : Konstanta \\
\hline $\begin{array}{llll}b_{1} & b_{2} & b_{3} & b_{4}\end{array}$ & : Koefisien Regresi \\
\hline $\mathrm{x}_{1}$ & Profitabilitas (Return On Asset) \\
\hline $\mathrm{x}_{2}$ & : Likuiditas (Current Ratio) \\
\hline $\mathrm{x}_{3}$ & : Solvabilitas \\
\hline $\mathrm{x}_{4}$ & : Ukuran Perusahaan \\
\hline e & : Error \\
\hline
\end{tabular}

Santoso (2012) mengemukakan bahwa langkah-langkah dalam pengujian hipotesis dengan regresi logistik antara lain menguji kelayakan model regresi, menguji keseluruhan model, dan menguji koefisien regresi.

Untuk melihat pengujian variabel bebas (independen) terhadap variabel terikat (dependen) digunakan dengan memperhatikan nilai Chi-Square. Dengan hipotesis:

\section{Ho : Tidak ada perbedaan yang nyata antara klasifikasi yang diprediksi dengan klasifikasi yang diamati. \\ Ha : Ada perbedaan yang nyata antara klasifikasi yang diprediksi}

Pengujian keseluruhan model regresi dilakukan dengan membandingkan nilai antara -2 log likelihood pada awal (block number $=0$ ) dengan nilai -2 log likelihood pada akhir (block number $=1$ ). Apabila hasil Block Number akhir lebih kecil dari pada hasil Block Number awal maka hal ini menunjukkan model regresi yang lebih baik.

ji t digunakan untuk menguji konstanta dari setiap variabel independen. Hipotesis yang diajukan dalam penelitian ini antara lain sebagai berikut: 
$\mathrm{H}_{\mathrm{o}}$ : Profitabilitas berpengaruh signifikan terhadap Ketepatan Waktu Penyampaian Laporan Keuangan terhadap Perusahaan Perbankan yang Terdaftar di Bursa Efek Indonesia

$\mathrm{H}_{1}$ : Profitabilitas tidak berpengaruh signifikan terhadap Ketepatan Waktu Penyampaian Laporan Keuangan terhadap Perusahaan Perbankan yang Terdaftar di Bursa Efek Indonesia

$\mathrm{H}_{\mathrm{o}}$ : Likuiditas berpengaruh signifikan terhadap Ketepatan Waktu Penyampaian Laporan Keuangan terhadap Perusahaan Perbankan yang Terdaftar di Bursa Efek Indonesia

$\mathrm{H}_{\mathrm{a}}$ : Likuiditas tidak erpengaruh signifikan terhadap Ketepatan Waktu Penyampaian Laporan Keuangan terhadap Perusahaan Perbankan yang Terdaftar di Bursa Efek Indonesia

$\mathrm{H}_{0}$ : Solvablitas berpengaruh signifikan terhadap Ketepatan Waktu Penyampaian Laporan Keuangan terhadap Perusahaan Perbankan yang Terdaftar di Bursa Efek Indonesia

$\mathrm{H}_{\mathrm{a}}$ : Solvabilitas tidak berpengaruh signifikan terhadap Ketepatan Waktu

Penyampaian

Laporan Keuangan terhadap perusahaan perbankan yang terdaftar di Bursa Efek Indonesia

$\mathrm{H}_{\mathrm{o}}$ : ukuran perusahaan berpengaruh signifikan terhadap ketepatan waktu penyampaian laporan keuangan pada perusahaan perbankan yang terdaftar di bursa efek Indonesia.

$\mathrm{H}_{\mathrm{a}}$ : ukuran perusahaan tidak berpengaruh signifikan terhadap ketepatan waktu penyampaian laporan keuangan pada perusahaan perbankan yang terdaftar di bursa efek Indonesia.

Dengan demikian hasil uji t pada bagian akhir Output, dapat diambil keputusan bahwa:

(a) Jika probabilitas $<0,05$ maka Ha diterima

(b) Jika probabilitas > 0,05 maka Ha ditolak dengan klasifikasi yang diamati.

Dasar pengambilan keputusan:

(a) Jika probabilitas $>0,05$ maka Ho diterima

(b) Jika probabilitas <0,05 maka Ho ditolak

\section{HASIL DAN PEMBAHSAN}

Uji Multikolinearitas bertujuan untuk menguji apakah model regresi ditemukan memiliki korelasi antar variabel bebas (variabel independen). Model regresi yang baik seharusnya tidak terjadi multikolinearitas. Uji multikolinearitas dilakukan dengan menghitung nilai VIF (Variance Inflantion Factor). Jika VIF > 10, maka dalam model regresi tersebut terjadi multikolinearitas, yang berarti terjadi kolinearitas yang tinggi di antara beberapa atau seluruh variabel independen dari penelitian

Tabel 4.10. Tolenrance Value dan VIF

\begin{tabular}{llcr}
\hline \multirow{2}{*}{ Model } & & \multicolumn{2}{c}{ Collinearity Statistics } \\
\cline { 3 - 4 } & & \multicolumn{2}{c}{ Tolerance } \\
\hline & (Constant) &, 668 & 1,126 \\
& Profitabilitas &, 834 & 1,199 \\
& Likuiditas &, 924 & 1,084 \\
& Solvabilitas &, 769 & 1,022 \\
\hline & Ukuran Perusahaan &
\end{tabular}

a. Dependent Variable: TimeLiness

Sumber: Data Penelitian diolah SPSS 21

Dari hasil output data didapatkan bahwa semua nilai VIF $<10$ ini berarti tidak terjadi multikolonieritas. Sehingga dapat disimpulkan tidak terdapat pengaruh antar variabel independen dan variabel dependent.

Uji autokorelasi bertujuan untuk mengetahui apakah dalam model regresi ada korelasi antar variabel. Salah satu cara yang dapat digunakan untuk mendeteksi ada atau tidaknya autokorelasi yaitu dengan menggunakan uji Durbin Watson ( $D$ - $W$ test).

Tabel 4.11. Hasil Perhitungan Uji Autokorelasi Model Summary ${ }^{\mathrm{b}}$

\begin{tabular}{lrrrrr}
\hline Model & $\mathrm{R}$ & R Square & $\begin{array}{c}\text { Adjusted R } \\
\text { Square }\end{array}$ & $\begin{array}{c}\text { Std. Error of the } \\
\text { Estimate }\end{array}$ & Durbin-Waston \\
\hline 1 &, $168^{\mathrm{a}}$ &, 035 &,- 020 &, 19365 & 2,021 \\
\hline
\end{tabular}


a. Predictors: (Constant), Ukuran Perusahaan, DER, CR, NPM

b. Dependent Variable: TimeLiness

Sumber : Data Penelitian dioleh SPSS21

Berdasarkan hasil yang ditunjukkan pada tabel 4.10 diperoleh nilai Durbin-Watson (DW) sebesar 1,556. Dengan demikian dapat dikatakan bahwa dalam model tidak terdapat autokorelasi.

\section{Pengujian Kelayakan Model}

Pengujian kelayakan model regresi logistic dilakukan dengan mengukur nilai Chi-Square pada bagian Hosmer and Lemeshow. Berdasarkan hasil pengolahan data dengan menggunakan software SPSS versi 21 diperoleh hasil sebagai berikut:

Tabel 4.12. Hasil Pengujian Kelayakan Model Hosmer and Lemeshow Test

\begin{tabular}{lrrr}
\multicolumn{5}{c}{ Hosmer and Lemeshow Test } \\
\hline Step & Chi-square & df & Sig. \\
\hline 1 & 3,370 & 8 &, 029 \\
\hline
\end{tabular}

Sumber : Data Penelitian diolah SPSS 21

Hasil uji Hosmer and Lemeshow dalam tabel 4.11 menunjukkan bahwa nilai Chi-Square sebesar 3,370 dengan nilai signifikan sebesar 0,029 lebih besar dari 0,05. Sehingga keputusan yang diambil adalah menerima Ho yaitu tidak ada perbedaan yang nyata antara klasifikasi yang diprediksi dengan klasifikasi yang diamati. Dengan demikian dapat disimpulkan bahwa model dapat diterima dan bisa digunakan untuk analiisis selanjutnya.

Pengujian keseluruhan model regresi dilakukan dengan membandingkan nilai antara -2 Log likelihood (-2LL) pada awal (Block Number $=0$ ) dengan nilai -2 Log likelihood (-2LL) pada akhir (Block Number $=1)$. Berdasarkan hasil pengolahan data dengan menggunakan software SPSS versi 21 diperoleh hasil sebagai berikut :

Tabel 4.13. Hasil Block Awal Pengujian Keseluruhan Model

Iteration story ${ }^{\mathrm{a}, \mathrm{b}, \mathrm{c}}$

\begin{tabular}{llrr}
\hline \multirow{2}{*}{ Iteration } & & -2 Log likelihood & \multicolumn{2}{c}{ Coefficients } \\
\cline { 4 - 4 } & & & \multicolumn{2}{c}{ Constant } \\
\hline \multirow{4}{*}{ Step 0} & 1 & 33,758 & 1,583 \\
& 2 & 32,124 & 2,051 \\
& 3 & 32,078 & 2,148 \\
& 4 & 32,078 & 2,015 \\
& 5 & 32,078 & 2,015 \\
\hline \hline
\end{tabular}

a. Constant is included in the model.

b. Initial -2 Log Likelihood: 32,078

c. Estimation terminated at iteration number 5 because parameter estimates

changed by less than ,001.

Sumber: Data Skunder yang dioleh dengan SPSS 21

Tabel 4.14. Hasil Block Akhir Pengujian Keseluruhan Model Iteration History ${ }^{\text {a,b,c,d }}$

\begin{tabular}{rrrrrrrr}
\hline \multirow{2}{*}{ Iteration } & \multicolumn{2}{c}{-2 Log } & \multicolumn{7}{c}{ Coefficients } \\
\cline { 3 - 8 } & 1 & likelihood & Constant & \multicolumn{1}{c}{ X1 } & \multicolumn{1}{c}{ X2 } & X3 & X4 \\
\hline \multirow{4}{*}{ Step 1 1} & 31,732 & 1,510 &,- 008 &,- 002 &, 000 &, 031 \\
& 2 & 29,497 & 1,902 &,- 013 &,- 003 &, 000 &, 053 \\
& 3 & 29,392 & 1,950 &,- 016 &,- 003 &, 000 &, 063 \\
& 4 & 29,391 & 1,945 &,- 016 &,- 003 &, 000 &, 064 \\
& 5 & 29391 & 1,945 &,- 016 &,- 003 &, 000 &, 064 \\
\hline
\end{tabular}



a. Method: Enter
b. Constant is included in the model.
c. Initial -2 Log Likelihood: 32,078
d. Estimation terminated at iteration number 5 because parameter estimates changed by less than ,001

Sumber: Data Skunder yang diolah dengan SPSS 21

Hasil pengujian keseluruhan model dalam tabel 4.12 dan tabel 4.13 menunjukkan nilai -2 Log likelihood pada blok awal adalah 32,078 sedangkan nilai -2 Log likelihood pada blok akhir menurun menjadi 32,067 Penurunan ini menunjukkan model regresi yang lebih baik. Berdasarkan output SPSS secara parsial pengaruh dari variabel independen yaitu profitabiitas, likuiditas, ukuran perusahaan, dan opini akuntan publik terhadap timeliness ditunjukkan pada tabel berikut ini

Tabel 4.15. Hasil Regresi Logistik Perusahaan yang Terdaftar di Bursa Efek Indonesia

\begin{tabular}{rlrrrrrrr}
\hline \multicolumn{10}{c}{ Variables in the Equation } \\
\hline & \multicolumn{1}{c}{ B } & \multicolumn{1}{c}{ S.E. } & Wald & Df & \multicolumn{1}{c}{ Sig. } & Exp(B) \\
\hline \multirow{3}{*}{ Step 1 } & X1 &, 003 &, 001 & 4,537 & & 1 &, 032 & 1,002 \\
& X2 &, 000 &, 000 & 1,178 & & 1 &, 027 & 1,000 \\
& X3 &, 000 &, 001 &, 030 & & 1 &, 363 & 1,253 \\
& X4 &,- 064 &, 302 &, 045 & & 1 &, 832 & 1,066 \\
& Constant & 1,945 & 5,053 &, 148 & & 1 &, 700 & 6,996 \\
\hline
\end{tabular}

a. Variable(s) entered on step 1: X1, X2, X3, X4.

Sumber: Daya skunder yang diolah dengan SPSS 21

Dengan melihat tabel 4.14 diatas, dapat disusun persamaan regresi logistik sebagai berikut :

Timeliness $=1,945+0,003 \mathrm{X}_{1}+0,000 \mathrm{X}_{2}+0,000 \mathrm{X}_{3}-0.064 \mathrm{X}_{4}+\mathrm{e}$

Dari hasil persamaan regresi logistik tersebut diatas maka dapat dianalisis sebagai berikut:

1) Konstanta $(\alpha)$

Ini berarti jika semua variabel bebas memiliki nilai nol (0) maka nilai variabel terikat (Timelinss) sebesar 1,945 .

2) Profitabiitas $\left(\mathrm{X}_{1}\right)$ terhadap Timeiness $(\mathrm{Y})$

Nilai koefisien profitabilitas untuk variabel $\mathrm{X}_{1}$ sebesar $0,003 \mathrm{Hal}$ ini mengandung arti bahwa setiap kenaikan Profitabilitas 1\% maka variabel Timeliness (Y) akan naik sebesar 0,003 dengan asumsi bahwa variabel bebas yang lain dari model regresi adalah tetap.

3) Likuiditas $\left(\mathrm{X}_{2}\right)$ terhadap Timeliness $(\mathrm{Y})$

Nilai koefisien Likuiditas untuk variabel $\mathrm{X}_{2}$ sebesar $0,000 \mathrm{Hal}$ ini mengandung arti bahwa setiap kenaikan Likuiditas $1 \%$ maka variabel Timeliness (Y) akan naik sebesar 0,000 dengan asumsi bahwa variabel bebas yang lain dari model regresi adalah tetap.

4) Solvabilitas $\left(\mathrm{X}_{3}\right)$ terhadap Timeliness $(\mathrm{Y})$

Nilai Koefisien Solvabilitas untuk Variabel $X_{3}$ sebesar 0,000 hal ini mengandung arti bahwa setiap kenaikan Solvabilitas 1\% maka variabel Timeliness (Y) akan naik sebesar 0,000 dengan asumsi bahwa variabel bebas yang lain dari model regresi adalah tetap.

5) Ukuran Perusahaan $\left(\mathrm{X}_{4}\right)$ terhadap Timeliness $(\mathrm{Y})$

Nilai koefisien Ukuran Perusahaan untuk variabel $\mathrm{X}_{4}$ sebesar -0,064 Hal ini mengandung arti bahwa setiap kenaikan Ukuran perusahaan 1\% maka variabel Timeliness (Y) akan turun sebesar -0,064 dengan asumsi bahwa variabel bebas yang lain dari model regresi adalah tetap.

Pengujian hipotesis dalam penelitian ini mengunakan tingkat keyakinan $95 \%$ dengan signifikasi $5 \%$ jika t lebih kecil dari $\alpha(0,05)$ maka variabel Independen tersebut berpengaruh signifikan terhadap variabel dependen. Namun, sebaliknya jika t lebih besar dari $\alpha(0,05)$ maka variabel independen tidak memiliki pengaruh signifikan terhadap variabel dependen.

Tabel 4.16. Hasil Uji t

Variables in the Equation

\begin{tabular}{|c|c|c|c|c|c|c|c|}
\hline & & B & S.E. & Wald & $\mathrm{df}$ & Sig. & $\operatorname{Exp}(B)$ \\
\hline Step $1^{2}$ & $\mathrm{X} 1$ & ,003 & ,001 & 4,537 & 1 &, 032 & 1,002 \\
\hline
\end{tabular}




\begin{tabular}{llrrrrrr}
\hline & X2 &, 000 &, 000 & 1,178 & 1 &, 027 & 1,000 \\
\cline { 2 - 8 } & X3 &, 000 &, 001 &, 030 & 1 &, 363 & 1,253 \\
\cline { 2 - 8 } X4 &,- 064 &, 302 &, 045 & 1 &, 832 & 1,066 \\
\cline { 2 - 8 } & Constant & 1,945 & 5,053 &, 148 & 1 &, 700 & 6,996 \\
\hline
\end{tabular}

Sumber: Data Skunder yang diolah dengan SPSS 21

Berdasarkan tabel 4.15 dapat dilihat pengaruh masing-masing variabel Profitabilitas, Likuiditas, Solvabilitas dan Ukuran Perusahaan terhadap Timeliness dapat dilihat dari arah tanda dan tingkat signifikansi (probabilitas).

Variabel Profitabilitas mempunyai nilai probabilitas sebesar 0,032 berarti Profitabilitas berpengaruh signifikan terhadap Timeliness karena nilai probabilitas signifikansi $>0,05$, berarti $\mathrm{H}_{1}$ diterima.

Variabel Likuiditas mempunyai nilai probabilitas sebesar 0,027 berarti Likuiditas berpengaruh signifikan terhadap Timeliness karena nilai probabilitas signifikansi $>0,05$, berarti $\mathrm{H}_{2}$ diterima.

Variabel Solvabilitas mempunyai nilai probabilitas sebesar 0,363 berarti Likuiditas tidak berpengaruh signifikan terhadap Timeliness karena nilai probabilitas signifikansi > 0,05, berarti $\mathrm{H}_{3}$ ditolak.

Variabel Ukuran Perusahaan mempunyai nilai probabilitas sebesar 0,832 berarti ukuran perusahaan tidak berpengaruh signifikan terhadap Timeliness karena nilai probabilitas signifikansi > 0,05 , berarti $\mathrm{H}_{4}$ ditolak.

\section{SIMPULAN}

Berdasarkan hasil analisis regresi logistic yang telah dilakukan dengan menggunakan Software SPSS versi 21, dapat ditarik kesimpulan sebagai berikut :

1. Profitabilitas yang diproaksikan dengan menggunakan Net Profit Margin berpengaruh signifikan terhadap timeliness. Dengan demikian $\mathrm{H}_{1}$ yang menyatakan bahwa Profitabilitas berpengaruh Signifikan terhadap timeliness pada perusahaan yang terdaftar di Bursa Efek Indonesia, diterima

2. Likuiditas yang diproaksikan dengan menggunakan Current Ratio berpengaruh Signifikan terhadap timeliness. Dengan demikian $\mathrm{H}_{2}$ yang menyatakan Likuiditas berpengaruh Signifikan terhadap timeliness pada perusahaan yang terdaftar di Bursa Efek, diterima.

3. Solvabilitas yang diproaksikan dengan menggunakan Debt to Equity tidak berpengaruh Signifikan terhadap timeliness. Dengan demikian $\mathrm{H}_{3}$ yang menyatakan Likuiditas berpengaruh Signifikan terhadap timeliness pada perusahaan yang terdaftar di Bursa Efek, diterima.

4. Ukuran Perusahaan yang diukur dengan menggunakan Logaritma Natural total asset (lnTA) tidak berpengaruh tidak Signifikan. Dengan demikian $\mathrm{H}_{4}$ yang menyatakan ukuran perusahaan berpengaruh Signifikan terhadap timeliness pada perusahaan yang terdaftar di Bursa Efek Indonesia, ditolak.

\section{DAFTAR PUSTAKA}

Agoes, S. dan Jan hoesada. 2009. Bunga Rumpai Auditing. Salemba Empat Jakarta.

Belkaoui, Ahmad Riahi.2007. Accounting Theory, $5^{\text {th }}$ edition. Yulianto, Ali A. dan Krista (terjemahan). Teori Akuntansi, Buku 2, edisi 5. Salemba Empat. Jakarta.

Hasniar, Farisah. 2012. Analisis Faktor-Faktor yang Mempengaruhi Ketepatan Waktu Penyampaian Laporan Keuangan ( Studi Empiris pada Perusahaan-Perusahaan Industri Barang Konsumsi yang Terdaftar di BEI Priode 2007-2011). Skripsi. Universitas Gunadarma. Depok

Hilmi, U. dan Syaiful Ali. 2008. Analisis Faktor-Faktor yang Mempengaruhi Ketepatan Waktu Penyampaian Laporan Keuangan ( Studi Empiris pada Perusahaan-Perusahaan yang Terdaftar di BEJ Priode 2004-2006). Simposium Nasional Akuntansi XI Pontianak. 23-24 juli: 1-26.

Hartono, Jogiyanto. 2007. Metodologi Penelitian Bisnis: Salah Kaprah dan Pengalaman-Pengalaman, Cetakan Pertama. BPEFE UGM. Yogyakarta. 
Home, James C. Van dan John M. Wachowicz, Jr. 2007. Fundamental of Financial Management, $12^{\text {th }}$ ed. Fitriasari, D. dan Deny Arnos Kwary (terjemahan). Prinsip-prinsip Manajemen Keuangan, Buku 2, Edisi 12. Salemba Empat Jakarta.

Islahuzzaman. 2012. Istilah-istilah Akuntansi dan Auditing, Edisi 1 Cetakan Pertama Bumi Aksara. Jakarta.

Kasneli, Weni Prisma. 2009. Pengaruh Rasio Keuangan, Ukuran Perusahaan, dan Opini Auditormterhadap Ketepatan Waktu Penyampaian Laporan Keuangan Pada Perusahaan Restoran, Hotel, dan Pariwisata yang Terdaftar di BEI. Skripsi. Universitas Pembangunan Nasional Veteran. Jakarta.

Keputusan Ketua Otoritas Jasa Keuangan Nomor: KEP-36/PM/2013 tentang kewajiban Penyampaian Laporan Keuangan Berkala. 30 September 2013. Jakarta.

Keputusan Ketua Badan Pengawas Pasar Modal Nomor: KEP-80/PM/1996 tentang Kewajiban Penyampaian Laporan Keuangan Berkala. 17 Januari 1996. Jakarta.

Keputusan Ketua Badan Pengawas Pasar Modal dan Lembaga Keuangan Nomor: KEP-346/BL/2011 tentang Kewajiban Penyampaian Laporan Keuangan Berkala Emiten atau Perusahaan Publik. 5 Juli 2011. Jakarta.

Keputusan Ketua Badan Pengawas Pasar Modal dan Lembaga Keuangan Nomor: KEP-40/BL/2007 tentang Jangka Waktu Penyampaian Laporan Keuangan Berkala Emiten atau Perusahaan Publik. 5 Juli 2007. Jakarta.

Martini, D., Sylvia Veronica NPS, Ratna Wardhani, Aria Farahmita, dan Edward Tanujaya. 2012. Akuntansi Keuangan Menengah Berbasis PSAK, Buku 1. Salemba Empat. Jakarta.

Research Division Indonesia Stock Exchange. 2010. IDX Fact Book 2010. Bursa Efek Indonesia. Jakarta. 2011. IDX Fact Book 2011. Bursa Efek Indonesia. Jakarta. 2012. IDX Fact Book 2012. Bursa Efek Indonesia. Jakarta. 2013. IDX Fact Book 2013. Bursa Efek Indonesia. Jakarta.

Rahardjo, Soemarso S. 2010. Akuntansi: Suatu Pengantar, Buku 2, Edisi 5, Cetakan Keempat. Salemba Empat. Jakarta.

Respati, Novita WeningTyas. 2004. Faktor-faktor yang Berpengaruh Terhadap Ketepatan Waktu Penyampaian Laporan Keuangan: Study Empiris di Bursa Efek Jakarta, Jurnal Maksi 4 (5) Januari: 67-81.

Samryn, L. M. 2011. Pengantar Akuntansi: Mudah Membuat Jurnal Dengan Pendekatan Siklus Transaksi, Jilid 1. Rajawali Pers. Jakarta.

Sutrisno, 2009. Manajemen Keuangan: Teori, Konsep, dan Aplikasi, Cetakan Ketujuh. Ekonosia. Yogyakarta. 